\title{
Early infant diagnosis: gateway to survival for HIV positive infants
}

\author{
Jayanthi Shastri, Sachee Agrawal, Sandhya Sawant, Manish Pathak \\ From 2nd International Science Symposium on HIV and Infectious Diseases (HIV SCIENCE 2014) \\ Chennai, India. 30 January - 1 February 2014
}

\section{Background}

Under PPTCT, babies born to sero-positive mothers were followed up and tested at 18 months of age. Under Early Infant Diagnosis (EID) program, HIV exposed babies are subjected to HIV-1 DNA PCR on DBS and whole blood as early as 6 weeks of age followed by initiation of ART.

\section{Methods}

Infants born to HIV positive mothers were tested according to NACO guidelines. Infants $<6$ months of age $(n=136)$ were tested by DBS HIV-1 DNA PCR; DBS positive were confirmed by whole blood PCR. Infants 6 to 18 months $(n=68)$ were tested by antibody test and if positive were confirmed by DBS HIV-1 DNA PCR. Detailed history including type of delivery, Single Dose Nevirapine (SDN) and breast feeding was taken.

\section{Results}

The HIV transmission rate was $11.28 \%$ (23/204); 13 infants $<6$ months of age and 10 infants $\geq 6$ months of age. In infants $<6$ months of age, who did not receive SDN the positivity was $38.46 \%(5 / 13)$ whereas in those who received SDN it was $6.5 \%(8 / 123),[p=0.0012]$. In infants $\geq 6$ months the positivity rate was significantly higher in breast fed $60 \%(6 / 10)$ as compared to non breast fed 6.9\% (4/58),[p=0.0001]. 60.9\% (14/23) infants were delivered at home and did not receive SDN.

\section{Conclusion}

In resource limited settings, SDN given to mother in labor is a good option.. Mothers intending to continue breast feeding should be provided extended ART. EID

\footnotetext{
* Correspondence: jsshastri@gmail.com

Department of Microbiology, T.N.Medical College and B.Y.L.Nair Charitable
} Hospital, Mumbai, India

Submit your next manuscript to BioMed Central and take full advantage of:

- Convenient online submission

- Thorough peer review

- No space constraints or color figure charges

- Immediate publication on acceptance

- Inclusion in PubMed, CAS, Scopus and Google Scholar

- Research which is freely available for redistribution 